\title{
IMPAIRED UP-EXPRESSION OF PRO-OXIDATION GENES BY OLIGORIBONUCLEOTIDES AT INFLUENZA A VIRUS INFECTION IN VIVO
}

\author{
N.S. Melnichuk', S.L. Rybalko', Z.Yu. Tkachuk'. \\ ${ }^{1}$ Institute of Molecular Biology and Genetics, NAS of Ukraine, \\ $150 \mathrm{Akad}$. Zabolotny Str., Kyiv, 03680, Ukraine \\ ${ }^{2}$ Gromashevsky Institute of Epidemiology and Infectious Diseases, NAMS of Ukraine, \\ 5 Amosov str., Kyiv, 03038, Ukraine \\ e-mail:natalia.melnichuk8@gmail.com
}

\begin{abstract}
Aim. Current research was aimed at study of the oligoribonucleotides effects on expression of the nos2, $x d h$, arg2 genes in mice lungs at influenza virus infection. Methods. To achieve this goal we applied a real-time polymerase chain reaction and lipid peroxidation assay. Results. In the present studies, we have found the mRNA up-expression of arg2, nos2, xdh after $48 \mathrm{~h}$ influenza virus infection. The oligoribonucleotides have been shown to impair the up-expression of nos $2, x d h$, arg2 genes induced by the influenza virus. They also decrease the level of lipid peroxidation products at influenza virus infection. Conclusions. Oligoribonucleotides normalize the overexpression of pro-oxidation genes induced by the influenza virus infection. By suppressing the up-regulation of these genes, oligoribonucleotides reduce the level of lipid peroxidation products at influenza virus infection. Impaired these genes overexpression at influenza virus infection can be one of elements of the mechanism action of the oligoribonucleotides as knew anti-influenza, antiinflammation drug.
\end{abstract}

Keywords: oligoribonucleotides, influenza, expression of nos2, xdh, arg2 genes.

Influenza virus belongs to the Orthomyxoviridae family and consists of four types: A, B, C and D. Among these types, the influenza A viruses cause major infections in respiratory tract of humans and lower mammals, and in gastrointestinal tract of birds, making it responsible for numerous deaths and great economic losses every year. Occasionally, the influenza A virus causes pandemics [1]. The lung is one of the most widely investigated targets for influenza virus infection [2]. Influenza virus induces lung pathology by releasing excessive amounts of reactive nitrogen intermediates (NO (nitric oxide), $\left.\mathrm{NO}_{2}, \mathrm{HNO}_{2}\right)$ and reactive oxygen species $\left(\mathrm{O}_{2}^{-}, \mathrm{OH}, \mathrm{H}_{2} \mathrm{O}_{2}^{-}\right)$[3]. Increased level of free radicals may directly contribute to cell death in highly pathogenic influenza virus-infected lung tissue and exacerbate pathology caused by virus replication during acute H5N1 infection [4]. The important pro-oxidation genes, which are responsible for generating free radicals, are $C y b b, X d h, N o s 2$ and Ncfl [5]. The pathogenic role of NO at influenza virus infection was demonstrated by a marked increase in the enzyme activity of NOS, and mRNA expression of nos 2, in influenza virus-infected lungs. $[5,6,7]$ Influenza virus induced pathological overproduction of oxygenfree radicals realizes by increasing in the enzyme activity of XO and mRNA expression of $x d h$ in mice $[5,8]$. Up-expression of nos 2 and $x d h$ induced by influenza virus infection is mediated by pro-inflammatory cytokines $[9,10]$. 
Natural oligoribonucleotides (ORNs) based on total yeast RNA have a wide range of biological activities and can be used in antiviral treatment, playing a key role in antiviral activity in vitro and in vivo [11]. It was shown in a study that oligoribonucleotides-D-mannitol (ORNs-D-M) complexes (total yeast RNA modified with D-mannitol (D-M)) intraperitoneal and intravenous injections to mice for the prevention in doses from 15 to $150 \mathrm{mg} / \mathrm{kg}$ have high anti-influenza activity. Intranasal administration of the ORNs-D-M for prevention in these same doses demonstrated anti-influenza activity 10-times higher compared to the intraperitoneal and intravenous injections [12]. Anti-influenza activity of the ORNs-D-M is attributed to inhibiting the neuraminidase activity [12] and hemagglutinin-glycan interaction of these viruses [13] in vitro. Furthermore, ORNs possess anti-inflammatory action and stabilize nitric oxide synthase (NOS) activity in vitro and in vivo [14]. It has not been determined that nos2, $x d h$, arg2 expression can change by the ORNs at influenza virus infection. Therefore, here we investigated influence of ORNs on expression of these genes with the aim of studying other mechanisms action of this drug as antiinfluenza therapeutic agent.

Materials and methods. ORNs - total yeast RNA with the dominant fraction of 3-8 nucleotides. The ORNs were purchased from Goodwill Associates, Inc. (Boca Raton, FL, USA). Mouse-adapted influenza virus A/FM/1/47 (H1N1) were obtained from National Virus Collection of D.I. Ivanovsky Institute of Virology of Russian Academy of Medical Science (Moscow, Russian Federation). BALB/c mice were obtained from M.M. ShemyakinYu.A. Ovchinnikov Institute of Bioorganic Chemistry of the Russian Academy of Sciences (Moscow, Russian Federation).

Mouse in vivo experiment. The BALB/c mice (14-16 g), 6 to 8 weeks of age, were distributed into five groups as follows: Control - healthy mice $(\mathrm{NaCl}$ injection, $0,9 \%)(\mathrm{n}=6),+$ ORNs - ORNs injection into healthy mice as positive control ORNs $(\mathrm{n}=6)$; +influenza - infection of mice with influenza virus as negative control $(\mathrm{n}=6)$; +ORNs+influenza - ORNs injection $24 \mathrm{~h}$ before influenza virus infection as prevention with ORNs $(n=6)$; +influenza+ORNs ORNs injection $24 \mathrm{~h}$ after influenza virus infection as treatment with ORNs $(\mathrm{n}=6)$. To infect each mouse were intranasal administrated $100 \mu \mathrm{L}$ of mouseadapted influenza virus A/FM/1/47(H1N1), $4.01 \mathrm{lg}_{50}$ diluted in sterile $\mathrm{NaCl}, 0,9 \%$. To prevention and treatment, each virus-infected mouse were intraperitoneal injected $100 \mu \mathrm{L}$ of the ORNs at concentration of $15 \mathrm{mg} / \mathrm{kg}$ (the minimal active concentration of ORNs) diluted in sterile $\mathrm{NaCl}, 0,9 \%$ [12]. After $48 \mathrm{~h}$ influenza virus infection the animals were sacrificed. All procedures, that were performed in studies, were in accordance with the ethical standards.

Real-Time qPCR assay. Total RNA was extracted from the lung (20 mg) by using a NucleoMag 96 RNA Kit (MACHEREY-NAGEL, Germany) and BeadRetriever system (Invitrogen, Finland), according to the protocol suggested by the manufacturer. RNA integrity was proven by Microchip electrophoresis system (MCE-202/MultiNA SHIMADZU, Germany), total RNA was quantified spectrometrically and RNA purity was assessed by the 260/280 nm ratio on a MaestroNano MN-913 spectrophotometer (MAESTROGEN, Taiwan). cDNA was synthesized from every total RNA sample by using a RevertAid H Minus First Standart cDNA Synthesis Kit (Thermo Scientific, USA). 
Random hexamer and oligo (dT) $)_{18}$ primers (1:3) were used and the protocol was as follows; incubating $120 \mathrm{~min}$ at $42{ }^{\circ} \mathrm{C}$, the reaction was heated to $70{ }^{\circ} \mathrm{C}$ for $5 \mathrm{~min}$ and chilled on ice. Reverse transcription was conducted using $2 \mu \mathrm{g}$ total RNA per sample. Messenger mRNA levels of $x d h, n o s 2$ and $\arg 2$ were quantified by a Thermal Cycler CFX96 Real-Time system (BIO-RAD, Singapore) using $10 \mu \mathrm{L}$ maxima SYBR Green/Flurescein qPCR masrer mix (Thermo Scientific, USA), $0.3 \mu \mathrm{L}$ cDNA sample, $1.5 \mu \mathrm{L}$ gene specific primers and $8.2 \mu \mathrm{L}$ nuclease-free water. Mice cDNA was amplified with the following primers: nos 2 F (5'- TTT GTG CGA AGT GTC AGT GG -3') and R (5'- TCC TTT GAG CCC TTT GTG C -3'), $\arg 2$ F (5'- TGA TTG GCA AAA GGC

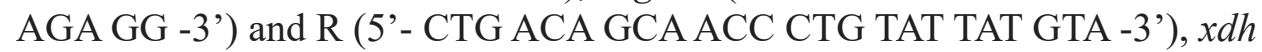
F (5'- CCA AGA TGG TTC AGG TGG C - $3^{\prime}$ ) and R (5'- TCT GAC AGG CTT CAT AAA TGG C -3'), gapdh F (5'-TGT CGT GGA GTC TAC TGG TGT CTT C-3') and R (5'-CGT GGT TCA CAC CCA TCA CAA-3'). Quantitative amplification conditions were as follows: denaturation at $95{ }^{\circ} \mathrm{C}$ for $10 \mathrm{~min}$, followed by 40 cycles of denaturation at $95^{\circ} \mathrm{C}$ for $40 \mathrm{~s}$, and annealing at $60{ }^{\circ} \mathrm{C}$ for $30 \mathrm{~s}$ and elongation at $72{ }^{\circ} \mathrm{C}$ for $30 \mathrm{~s}$. The $x d h, n o s 2$ and $\arg 2$ primer sequences were designed on GenBank database. Average fold change values were determined by $2^{(-\Delta \Delta C t)}$ method [15]. The samples were normalised to gapdh mRNA as a control and expression of gapdh mRNA were expressed as 100 expression units.

Lipid peroxidation. Mouse lungs were homogenized by liquid nitrogen and were soluted into $3 \mathrm{~mL}$ of $50 \mathrm{mM}$ PBS, $\mathrm{pH}=7.4$. After into $100 \mu \mathrm{L}$ of the homogenized sample was added $2.5 \mathrm{~mL}$ of $0.025 \mathrm{M}$ трис- $\mathrm{HCl} \mathrm{pH=7.4}$ (with $0.175 \mathrm{M} \mathrm{KCl}$ ), $1 \mathrm{~mL}$ of $17 \%$ of trichloroacetic acid solution and was centrifuged at $4000 \mathrm{~g}$ for $10 \mathrm{~min}$ at $4{ }^{\circ} \mathrm{C}$. Protein was measured by the method of Lowry et al. [16]. Endogenous LPO products reacting with 2-thiobarbituric acid (TBA-reactive substances, TBARS) were measured as described by Asakawa \& Matsushita [17] using SPECORD 210 Plus (Analytik Jena AG, Germany) at a $532 \mathrm{~nm}$ wavelength.

Statistical analysis. The data were analysed with one-way analysis of variance (anova) followed by Student t-test. All the results are expressed as mean \pm SD.

Results. ORNs inhibit the up-expression of nos2, arg2, xdh genes induced by influenza virus in vivo.

To determine the influence of ORNs on the up-expression of some prooxidation gene induced by influenza virus, the mRNA levels of $n o s 2$, arg2 and $x d h$ in mice lungs were determined by RT-qPCR after prevention and treatment with ORNs of the influenza virus infection. As shown in Figure1 the significant overexpression $(p<0.05)$ of all investigated genes was detected in mice lungs after $48 \mathrm{~h}$ influenza virus infection compared to the control. Conversely, at ORNs injection into healthy mice as positive control ORNs the mRNA expression levels of $n o s 2$, $\arg 2$ and $x d h$ remained unchanged compared to the healthy ones. The ORNs injection for prevention significantly reduced the mRNA level of nos 2 and $x d h$ expression $(\mathrm{p}<0.05)$ in comparison to the virus-infected mice, whereas the ORNs injection for treatment insignificantly decreased the mRNA level of nos 2 and $x d h$ expression in comparison to the virus-infected mice. At prevention and treatment with the ORNs was also 
detected an insignificantly decreased the mRNA level of arg2 compared to the control.

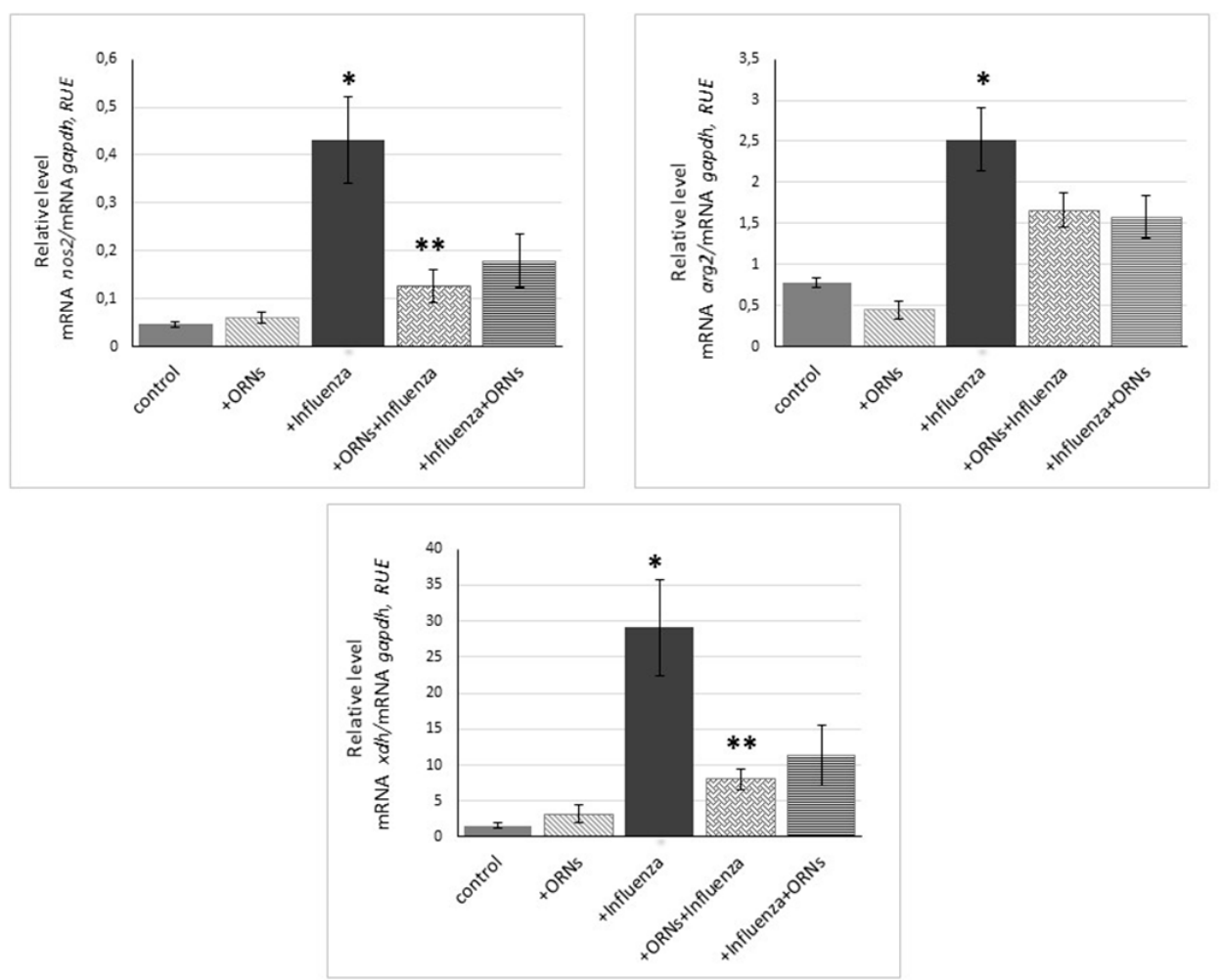

Fig. 1. Impair up-regulation of nos2, arg $2, x d h$ induced by influenza virus owing to ORNs in vivo. RUE: relative units of expression. Data are shown as the mean $\pm \mathrm{SD}$ for three independent experiments. Statistical significance was evaluated using the Student's t-test, relative to the control $(* \mathrm{p}<0.05)$ and to the influenza infected mice $(* * \mathrm{p}<0.05)$.

Decrease level of LPO products by the ORNs in lung of influenza-infected mice. After $48 \mathrm{~h}$ influenza virus infection and both prevention and treatment with the ORNs, the level of LPO products in mice lungs was measured by thiobarbituric acid reactive species (TBARS). The level of TBARS in influenza infected mice lungs was found to be high by $48 \%$ compared to control, whereas both prevention and treatment with the ORNs of the influenza virus infection decreased the TBARS level by 20 and $15 \%$ respectively in compering to influenza-infected mice (Figure 2). Unchanged the TBARS level was observed in mice lungs after ORNs injection without the influenza virus infection compared to control.

Discussion. Currently, two options are available to fight influenza: vaccination and antiviral drugs. Vaccination is a key component of defense strategies against influenza, although effective vaccines cannot be produced quickly enough to deal with emerging threats. Anti-influenza drugs include the adamantanes, which target the M2 and inhibit viral uncoating, and NA inhibitors, which block the release of virions from infected cells. Unfortunately, the emergence of strains resistant to antiviral agents highlights the need for drugs that act on new molecular targets, furnishing safe and effective protection against 
influenza [18]. In this context, targeting of interactions between virus and host cell has been proposed as a novel antiviral strategy that could reduce both viral replication and lung inflammation, as resistance is less likely to occur [19].

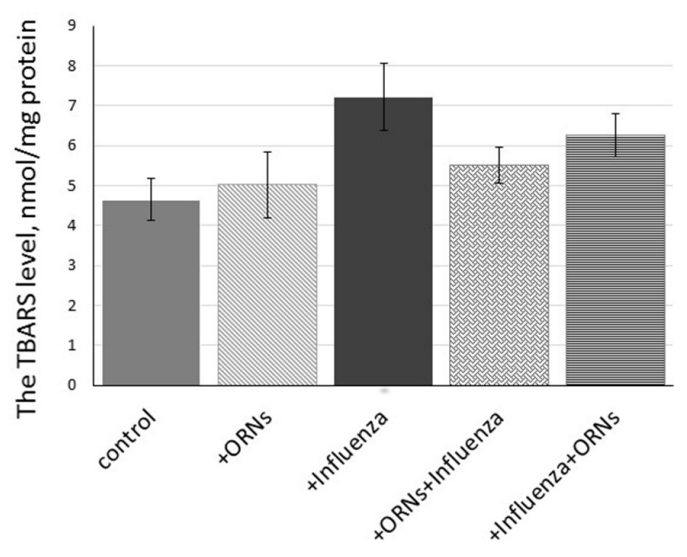

Fig. 2. Decrease level of LPO products in lung of influenza virus infected mice by the ORNs. Data are shown as the mean \pm SD for three independent experiments.

As it was mentioned above, oligoribonucleotides (ORNs) and their complexes with D-mannitol based on total yeast RNA have antiviral activity against DNA and RNA viruses [11]. Recently, our results showed that one of mechanisms of the ORNs-D-M anti-influenza activity is direct virucidal action by blocking HA-glycan interactions [13] and inhibiting neuraminidase activity of influenza virus [12] in vitro.

Influenza infections of the airways lead to inflammation that is most intense in the epithelial layer and induce an up-expression of pro-oxidation in mice lung $[3,5,8,10]$. In the presented study, we found the mRNA overexpression of nos 2 and $x d h$ after $48 \mathrm{~h}$ the influenza virus infection and that ORNs can reduce the mRNA up-expression of nos 2 and $x d h$ induced by the influenza virus infection. The ORNs preventive injections reduce high the mRNA level of nos 2 and $x d h$, induced by the influenza virus infection, more effectively $(\mathrm{p}<0.05)$ than the ORNs treatment injections.

Oxidative stress induced by overproduction of free radical, increases LPO level during influenza virus H1N1 infection [20]. Next, we estimated an ability of the ORNs to affect the level of LPO products in mice lungs at the influenza virus infection and detected that the ORNs injection for prevention and treatment can decrease the level of LPO products by 20 and $15 \%$ respectively in influenza infected mice, indicating that these ORNs probable decrease of the protein level of nos 2 and $x d h$ at the influenza virus infection. Activation of arginase in the airway epithelial cells leads to a reduction in iNOS mRNA and protein expression, as such reducing NO generation [21]. In our study, we found that influenza virus upregulated the mRNA expression $\arg 2(\mathrm{p}<0.05)$ 
and that the ORNs decrease overexpression of this gene at the influenza virus infection. These results suggest that the ORNs can modulate pro-inflammatory cytokines [22], impair the up-regulation of $n o s 2, x d h$, $\arg 2$ genes and increase LPO products induced by influenza virus, suppressing NOS activity and stabilizing membrane $[14,23]$.

Our results show that by ORNs inhibit up-expression of pro-oxidation genes $(n o s 2, x d h)$ induced by influenza virus infection. Impairing upexpression of nos $2, x d h$ can be mechanism of the ORNs action as know antiinfluenza virus drug with effective anti-inflammation activity. We believe that the oligoribonucleotides impair overexpression of pro-oxidation genes by inhibiting expression of the Toll-like receptors 3, 7 and 8. In future research, the expression of Toll-like receptors 3, 7 and 8 at influenza infection should be studied to understand the mechanism of ORNs normalization of expression pro-oxidation genes.

\title{
ПОРУШЕННЯ НАДЕКСПРЕСІЇ ПРО-ОКСИДАНТНИХ ГЕНІВ ОЛГГОРИБОНУКЛЕОТИДАМИ ПІД ЧАС ІНФЕКЦЇ̈ ВIРУСУ ГРИПУ А IN VIVO
}

\author{
Н.С. Мельнічук', С.Л. Рибалко², 3.Ю. Ткачук ${ }^{1}$ \\ ${ }^{1}$ Інститут молекулярної біології і генетики НАН України, \\ вул. Акад. Заболотного, 150, Київ, 03680, Украӥна \\ ${ }^{2}$ Інститут епідеміологї та інфекиійних захворювань \\ імені Л.В. Громамевського НАМН Украӥни, \\ вул. Амосова, 5, Київ, 03038, Украӥна
}

\section{Резюме}

Мета. Вивчення впливу олігорибонуклеотидів на експресію генів $n o s 2, x d h, \arg 2$ у легенях мишей під час інфекції вірусу грипу. Методи. Для досягнення мети ми застосували полімеразну ланцюгову реакцію у режимі реального часу та аналіз перекисного окиснення ліпідів. Результати. Надмірну експресію мРНК генів nos2, $x d h, \arg 2$ було виявлено після 48-годинного інфікування вірусом грипу. Показано, що олігорибонуклеотиди перешкоджають надмірній експресії генів nos 2, xdh, arg2, яка індукована вірусом грипу. Вони також зменшують рівень продуктів перекисного окиснення ліпідів при інфікуванні вірусом грипу. Висновки. Олігорибонуклеотиди нормалізують підвищену регуляцію про-оксидантних генів, яка індукована інфекцією вірусу грипу. Пригнічуючи надекспресію цих генів, олігорибонуклеотиди знижують рівень перекисного окиснення ліпідів під час інфекції вірусу грипу. Порушення надекспресії даних генів під час інфекції вірусу грипу може бути одним із елементів механізму дії олігорибонуклеотидів, відомого протизапального та протигрипозного препарату.

Ключові слова: олігорибонуклеотиди, грип, експресія генів nos2, xdh, arg2. 


\title{
НАРУШЕНИЕ НАДЭКСПРЕССИИ ПРО-ОКСИДАНТНЫХ ГЕНОВ ОЛИГОРИБОНУКЛЕОТИДАМИ ПРИ ИНФЕКЦИИ ВИРУСА ГРИППА А IN VIVO
}

\author{
Н.С. Мельничук ${ }^{1}$, С.Л. Рыбалко ${ }^{2}$, 3.Ю. Ткачук ${ }^{1}$ \\ ${ }^{1}$ Інститут молекулярной биологии и генетики НАН Украины, \\ ул. Акад. Заболотного, 150, Киев, 03680, Украина \\ ${ }^{2}$ Институт эпидемиологии и инфекиионных заболеваний \\ имени Л.В. Громатевского НАМН Украины, \\ ул. Амосова, 5, Киев, 03038, Украина \\ Резюме
}

Цель. Изучение влияния олигорибонуклеотидов на экспрессию генов $n o s 2, x d h$, $\arg 2$ в легких мышей при инфекции вируса гриппа. Методы. Для достижения цели мы применили полимеразную цепную реакцию в реальном времени и анализ перекисного окисления липидов. Результаты. Чрезмерная экспрессия мРНК генов nos 2, $x d h, \arg 2$ была обнаружена после 48-часового инфицирования вирусом гриппа. Показано, что олигорибонуклеотиды препятствуют чрезмерной экспрессии генов nos 2 , $x d h, \arg 2$, индуцированной вирусом гриппа. Они также уменьшают уровень продуктов перекисного окисления липидов при инфицировании вирусом гриппа. Выводы. Олигорибонуклеотиды нормализуют чрезмерную регуляцию про-оксидантных генов при инфекции вируса гриппа. Подавляя надрегуляцию этих генов, олигорибонуклеотиды снижают уровень перекисного окисления липидов при инфекции вируса гриппа. Нарушение надэкспрессии данных генов при инфекции вируса гриппа может быть одним из элементов механизма действия олигорибонуклеотидов, известного противовоспалительного и противогриппозного препарата.

Ключевые слова: олигорибонуклеотиды, грипп, экспрессия генов nos2, xdh, arg2.

1. Garten R.J., Davis C.T., Russell C.A., Shu, B. Lindstrom, S., Balish, A. Antigenic and genetic characteristics of swine-origin $2009 \mathrm{~A}(\mathrm{H} 1 \mathrm{~N} 1)$ influenza viruses circulating in humans. Science. 2009; 325:197-201.

2. Cees J., Doelman A., Aalt B. Oxygen radicals in lung pathology. Free Rad. Biol. Med. 1991; 9:381-400.

3. Akaike T. Role of free radicals in viral pathogenesis and mutation. Rev Med Virol. 2001; 11(2):87-101.

4. Perrone L.A., Belser J.A., Wadford D.A., Katz J.M., Tumpey T.M. Inducible Nitric Oxide Contributes to Viral Pathogenesis Following Highly Pathogenic Influenza Virus Infection in Mice. Infectious Diseases. 2013; 207(10):1576-1584.

5. Zou W.1., Chen D., Xiong M., Zhu J., Lin X., Wang L., et al. Insights into the increasing virulence of the swine-origin pandemic H1N1/2009 influenza virus. Sci Rep. 2013; 3:1601.

6. Dawson T.C., Beck M.A., Kuziel W.A., Henderson F., Maeda N. Contrasting effects of CCR5 and CCR2 deficiency in the pulmonary inflammatory response to influenza A virus. Am J Pathol. 2000; 156:1951-1959.

7. Uetani K.1., Der S.D., Zamanian-Daryoush M., de La Motte C., Lieberman B.Y., Williams B.R., Erzurum S.C. Role of Double-Stranded RNA-Activated Protein Kinase in Microbial Induction of Nitric Oxide Synthase1. Immunol. 2000; 165(2):988-996. 
8. Akaike T.1., Ando M., Oda T., Doi T., Ijiri S., Araki S., Maeda H. Dependence on $\mathbf{0}_{2}$ Generation by Xanthine Oxidase of Pathogenesis of Influenza Virus Infection in Mice. J Clin Invest. 1990; 85(3):739-45.

9. Akaike T., Noguchi Y., Ijiri S., Setoguchi K., Suga M., Zheng Y.M., et al. Pathogenesis of influenza virusinduced pneumonia: involvement of both nitric oxide and oxygen radicals. Proc. Natl. Acad. Sci. USA. 1996; 93:2448-53.

10. Akaike T., Maeda H. Nitric oxide and virus infection. Immunology. 2000; 101: 300-8.

11. Tkachuk Z. Multiantivirus Compound, Composition and Method for Treatment of Virus Diseases. U.S. Patent 20,120,232,129, 16 April 2013.

12. Tkachuk Z.Y., Rybalko S.L., Zharkova L.D., Starostyla D.B. [Antiinfluenzal activity of drug Nuclex]. Rep. Natl. Acad. Sci. Ukr. 2010; 9:191-196. Ukrainian.

13. Melnichuk N.S., Semernikova L.I., Tkachuk Z.Yu. Complexes of Oligoribonucleotides with D-mannitol inhibit hemagglutinin-glycan interaction and suppress influenza A virus H1N1 (A/FM/1/47) infectivity In Vitro. Pharmaceuticals. 2017; 10 (71):1-9.

14. Tkachuk Z.Yu., Tkachuk V.V., Tkachuk L.V. The study on membrane-stabilizing and anti-inflammatory actions of yeast RNA in vivo and in vitro. Biopolym. Cell. 2006; 22(2):109-116. Ukrainian.

15. Livak K.J., Schmittgen T.D. Analysis of relative gene expression data using real-time quantitative PCR and the 2(-delta delta C(T)) method. Methods. 2001; 25:402-408.

16. Lowry O.H., Rosebrough N.J., Farr A.L., Randall R.J. Protein measurement with the Folin phenol reagent. J Biol Chem. 1951; 193(1):265-75.

17. Asakawa T., Matsushita S. Thiobarbituric acid test for detecting lipid peroxides. Lipids. 1980; 14:401-406.

18. De Clercq, E. Human viral diseases: what is next for antiviral drug discovery? Curr. Opin. Virol. 2012; 2:572-579.

19. Sgarbanti R., Amatore D., Celestino I., Marcocci M E., Fraternale A., Ciriolo M. R., et al. Intracellular Redox State as Target for Anti-Influenza Therapy: Are Antioxidants Always Effective? Curr Top Med Chem. 2014; 14(22):2529-2541.

20. Nikam S.V., Nikam P.S., Chandrashekar M.R., Kalsad S.T., Jnaneshwara K.B. Role of lipid peroxidation, glutathione and antioxidant enzymes in H1N1 Influenza. Biomedical Research. 2010; 21(4):457-560.

21. Lucas R.1., Czikora I., Sridhar S., Zemskov E.A., Oseghale A., Circo S., et al. Arginase 1: an unexpected mediator of pulmonary capillary barrier dysfunction in models of acute lung injury. Front Immunol. 2013; 4:228.

22. Zelyoniy I.I., Tkachuk Z.Yu., Afonin D.N., Tiutiunnyk A. A. [Effect of Nuclex on the cytokine profile of patient with diabetes mellitus type 2 and neuropathic form of diabetic foot syndrome]. Natl. Acad. Med. Ukr. 2014; 20(2):240-245. Ukrainian.

23. Tkachuk Z. Method of protecting erythricytes, in particular for improvement of blood cytopenia. U.S. Patent 6,737,271. 26. 03. 2001.

Отримано 1.12.2017 